\title{
Mediastinal involvement in ovarian cancer
}

\author{
Nwabundo Nwankwo, Alan D Gilman, Aibek E Mirrakhimov, \\ Nkemakolam A Iroegbu
}

Department of Internal Medicine, Saint Joseph Hospital, Chicago, Illinois, USA

\section{Correspondence to Dr Aibek E Mirrakhimov, amirrakhimov1@gmail.com}

\section{DESCRIPTION}

A 57-year-old woman was diagnosed with serous papillary ovarian adenocarcinoma, for which she underwent total abdominal hysterectomy, bilateral salpingo-oophorectomy, omentectomy and appendectomy (omentum, appendix and other organs other than left ovary were grossly normal). CT scan of the chest was done, which showed prevascular lymph node measuring up to $4.5 \mathrm{~cm}$ (figure 1). The lymph node was biopsied, which stained positive for cytokeratin 7 and Wilms tumor gene product (WT)-1, which consistent with metastatic ovarian adenocarcinoma (figure 2). The patient was recently started on chemotherapy including carboplatin and paclitaxel, and radiation therapy.

Ovarian cancer is the second most common gynaecological cancer after breast cancer and the leading cause of gynaecological cancer-related

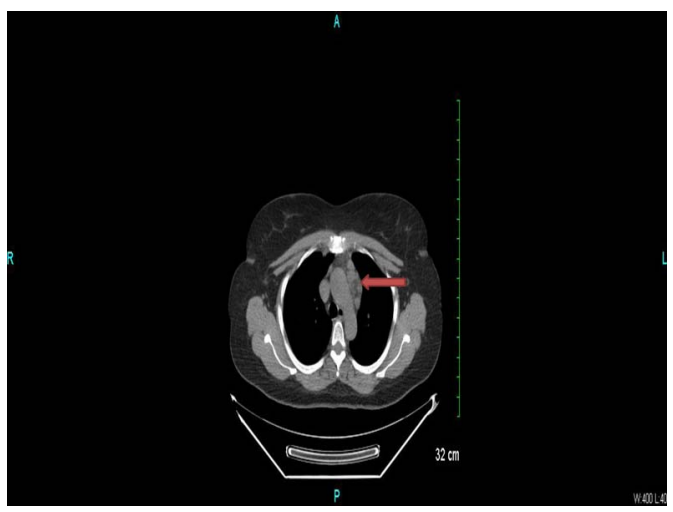

Figure 1 CT scan of the chest showing prevascular lymph node (red arrow).

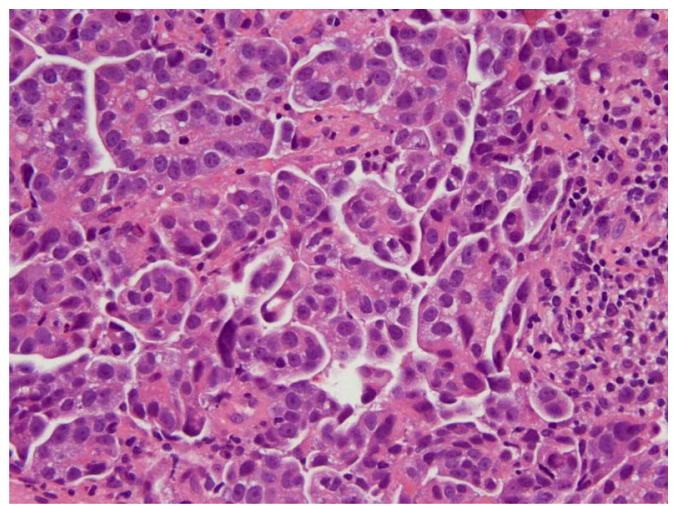

Figure 2 The lymph node biopsy consistent with metastatic ovarian carcinoma. deaths. ${ }^{1}$ Lymphatic spread and direct peritoneal tumour seeding are the most common metastatic routes of ovarian cancer. ${ }^{2}$ Mediastinal involvement is a rare phenomenon in patients with ovarian adenocarcinoma, with a few reports being published in the scientific literature..$^{3-6}$

Mediasintal involvement is an ominous sign, which indicates an advanced disease stage and poor prognosis. Clinicians should be aware that mediastinum may be involved in cases of ovarian cancer, even after performing debulking surgery for a primary ovarian tumour such as in our case.

\section{Learning points}

- Ovarian cancer is the second most common gynaecological malignancy, being the leading cause of gynaecological cancer-related mortality.

- Lymphatic spread and direct peritoneal tumour seeding are the most common metastatic routes of ovarian cancer.

- Mediastinal involvement is rare in patients with ovarian cancer, yet possible. Mediastinal involvement is associated with advanced disease stage and poor prognosis.

Contributors Each author contributed equally to this manuscript. Competing interests None.

Patient consent Obtained.

Provenance and peer review Not commissioned; externally peer reviewed.

\section{REFERENCES}

1 Siegel R, Naishadham D, Jemal A. Cancer statistics, 2012. CA Cancer J Clin 2012:62:10-29.

2 Mould T. An overview of current diagnosis and treatment in ovarian cancer. Int I Gynecol Cancer 2012;22(Suppl 1):S2-4.

3 Lu Y, Goldblatt JC. Multiple mediastinal metastasis of ovarian carcinoma. Heart Lung Circ 2005;14:118-20.

4 Moran CA, Suster S, Silva EG. Low-grade serous carcinoma of the ovary metastatic to the anterior mediastinum simulating multilocular thymic cysts: a clinicopathologic and immunohistochemical study of 3 cases. Am I Surg Pathol 2005:29:496-9.

5 Scarci M, Attia R, Routledge T, et al. A rare case of high-grade serous ovarian epithelial carcinoma presenting as an isolated cystic mediastinal mass: a case report and brief review of the literature. Ann R Coll Surg Engl 2010;92:W57-8.

6 Ragusa M, Vannucci J, Capozzi R, et al. Isolated cardiophrenic angle node metastasis from ovarian primary. report of two cases. J Cardiothorac Surg 2011;6:1. 


\section{Images in...}

Copyright 2013 BMJ Publishing Group. All rights reserved. For permission to reuse any of this content visit http://group.bmj.com/group/rights-licensing/permissions.

BMJ Case Report Fellows may re-use this article for personal use and teaching without any further permission.

Become a Fellow of BMJ Case Reports today and you can:

- Submit as many cases as you like

- Enjoy fast sympathetic peer review and rapid publication of accepted articles

- Access all the published articles

- Re-use any of the published material for personal use and teaching without further permission

For information on Institutional Fellowships contact consortiasales@bmjgroup.com

Visit casereports.bmj.com for more articles like this and to become a Fellow 